\title{
Efficacy of different doses and time intervals of oral vitamin D supplementation with or without calcium in elderly nursing home residents
}

\author{
V. Chel • H. A. H. Wijnhoven • J. H. Smit • \\ M. Ooms • P. Lips
}

Received: 12 June 2007 / Accepted: 21 August 2007 / Published online: 14 September 2007

(C) International Osteoporosis Foundation and National Osteoporosis Foundation 2007

\begin{abstract}
Summary The effect of equivalent oral doses of vitamin D3 $600 \mathrm{IU} /$ day, $4200 \mathrm{IU} /$ week and 18,000 IU/month on vitamin $\mathrm{D}$ status was compared in a randomized clinical trial in nursing home residents. A daily dose was more effective than a weekly dose, and a monthly dose was the least effective. Introduction It is assumed that equivalent daily, weekly or monthly doses of vitamin D3 equally influence vitamin D status. This was investigated in a randomized clinical trial in nursing home residents.

Methods The study was performed in ten nursing homes including 338 subjects ( 76 male and 262 female), with a mean age of 84 ( \pm SD 6.3 years). They received oral vitamin D3 either $600 \mathrm{IU} /$ day, or $4200 \mathrm{IU} /$ week, or 18,000 IU/month or placebo. After 4 months, calcium was added during 2 weeks, $320 \mathrm{mg} /$ day or $640 \mathrm{mg} /$ day or placebo. Outcome: serum levels of 25-hydroxyvitamin D $(25(\mathrm{OH}) \mathrm{D})$, parathyroid hormone (PTH) and bone turnover markers. Statistical approach: linear multilevel analysis.

Results At baseline, mean serum 25(OH)D was $25.0 \mathrm{nmol} / \mathrm{L}$
\end{abstract} (SD 10.9), and in $98 \%$, it was lower than $50 \mathrm{nmol} / \mathrm{L}$. After

V. Chel

Verpleeghuis Marienhave,

Warmond, The Netherlands

V. Chel · H. A. H. Wijnhoven · M. Ooms · P. Lips EMGO Institute, VU University Medical Center,

Amsterdam, The Netherlands

J. H. Smit

Department of Psychiatry, VU University Medical Center,

Amsterdam, The Netherlands

P. Lips $(\bowtie)$

Department of Endocrinology, VU University Medical Center,

P.O. Box 7057, 1007 MB Amsterdam, The Netherlands

e-mail: p.lips@vumc.nl
4 months, mean serum 25(OH)D levels increased to $62.5 \mathrm{nmol} / \mathrm{L}$ (after daily vitamin D3 $69.9 \mathrm{nmol} / \mathrm{L}$, weekly $67.2 \mathrm{nmol} / \mathrm{L}$ and monthly $53.1 \mathrm{nmol} / \mathrm{L}, \mathrm{P}<0.001$ between groups). Median serum PTH levels decreased by $23 \%$ ( $<<$ 0.001). Bone turnover markers did not decrease. Calcium supplementation had no effect on serum PTH and bone turnover.

Conclusion Daily vitamin D was more effective than weekly, and monthly administration was the least effective.

Keywords Calcium supplementation .

Secondary hyperparathyroidism · Vitamin D deficiency .

Vitamin D supplementation

\section{Introduction}

Vitamin D deficiency is common in older persons, in particular in residents of homes for the elderly and nursing homes and in patients with hip fracture [1-3]. In these groups the prevalence of vitamin $\mathrm{D}$ deficiency, defined at that time as serum $25(\mathrm{OH}) \mathrm{D}<30 \mathrm{nmol} / \mathrm{L}$ based on values in healthy blood donors, was reported to be $75 \%$ [3]. This is mainly explained by the fact that older persons do not often go outside in the sunshine and dietary vitamin D intake is low. Vitamin D deficiency causes secondary hyperparathyroidism, which leads to cortical bone loss, osteoporosis and fractures [4]. It may also cause fatigue, muscle weakness, increased body sway and falls $[5,6]$. Vitamin D supplementation in vitamin $\mathrm{D}$ deficient elderly increases the serum concentration of 25-hydroxyvitamin D (25(OH)D) and decreases the serum concentration of parathyroid hormone (PTH) [3]. It also decreases wintertime bone loss from the lumbar spine [7] and increases bone mineral density of the femoral neck [8]. Vitamin D supplementation 
combined with calcium decreased body sway and falls in a German study [5] and decreased hip as well as other nonvertebral fractures in French nursing home residents [9], whereas the results in more healthy elderly, living independently in the community were equivocal [10-14].

Vitamin D status in the elderly may be improved by ultraviolet irradiation [15] or by vitamin D supplementation $[3,7,8-14]$. Some controversy exists on the required serum 25(OH)D level, but most investigators agree that the level should be at least 50 or even $75 \mathrm{nmol} / 1[16,17]$.

The Dutch Health Council advises vitamin D 600 IU daily for elderly of 70 years and older who do not come outside in the sunshine [18]. Oral vitamin D3 can be taken once a day but also with longer intervals because of its long half life, being around 25 days. It is not known whether equivalent doses once a week or once a month are equally effective.

A low calcium intake aggravates vitamin $\mathrm{D}$ deficiency by increasing the turnover of vitamin $\mathrm{D}$ metabolites by secondary hyperparathyroidism [4]. On the other side, a high calcium intake does not completely protect against secondary hyperparathyroidism, and thus cannot compensate for vitamin D insufficiency [19]. The calcium requirement for skeletal maintenance is raising with age whereas the capacity for compensating a low calcium intake declines with age [20]. In the Netherlands the mean daily calcium intake of independently living elderly in homes and apartments of the elderly is about $900 \mathrm{mg}$ [2]. In the guidelines of the Dutch Health Council, the advised daily amount of calcium for elderly 70 years and older is $1200 \mathrm{mg}$ [18].

The aim of the present study was to investigate, in a Dutch nursing home population, whether there is a difference in efficacy of different doses and intervals of oral vitamin D3 supplementation with the same total dose. A second aim was to assess the additional effect of calcium supplementation following vitamin D supplementation on serum PTH and markers of bone turnover.

\section{Subjects and methods}

\section{Subjects}

Ten somatic and psychogeriatric nursing homes participated and 1,006 subjects were invited. Of these, $146 \mathrm{did}$ not respond, 386 refused to participate and 136 did not meet inclusion criteria. Participants were 338 (76 male and 262 female) patients of 70 years or older with a mean age of 84 years (SD 6.2). Exclusion criteria were going outside in the sunshine more than once a week, the use of vitamin D or calcium supplementation, the use of more than one vitamin Dfortified food or drink per day, complete immobilisation and a very poor life expectancy. Poor cognition was not an exclusion criterion. This did not affect adherence. Nursing homes were enrolled in the study throughout the year. Participants living together in the same nursing home started the study during the same season. The dietary vitamin D intake was estimated at about $100 \mathrm{IU} /$ day, based on fish and margarine consumption. In the Netherlands only margarine is fortified with vitamin D3 $(3 \mathrm{IU} / \mathrm{g})$ and the diet does not contain vitamin D2. Written informed consent was obtained from participants or their proxies. The protocol as well as the patient information letters were approved by the Ethical Review Board of the VU University medical centre.

\section{Randomisation}

Participants were randomised in blocks of six, to receive, during the study period of four and a half months, either oral vitamin D3 $600 \mathrm{IU} /$ day (one tablet) or placebo, $4200 \mathrm{IU} /$ week (seven tablets once a week) or placebo or $18,000 \mathrm{IU} / \mathrm{month}$ (one powder once a month) or placebo. (Solvay Pharmaceuticals, Weesp, Netherlands). After four months, participants in every group were randomised again to receive during 14 days either calcium carbonate or placebo. The first 156 participants who were randomised received $800 \mathrm{mg}$ calcium carbonate (320 mg Ca2+) or placebo, the subsequent 120 participants received $1,600 \mathrm{mg}$ calcium carbonate $(640 \mathrm{mg} \mathrm{Ca} 2+)$ or placebo. The study medication was centrally distributed to ensure compliance. The study was completed by 269 patients.

\section{Measurements}

At baseline co-medication was registered and a questionnaire for dietary calcium intake was used to calculate the mean daily calcium intake from dairy products, underestimating calcium intake by $200-300 \mathrm{mg} /$ day $[2,21]$.

The ability of standing and walking was assessed by a standing score, ranging from 1 (cannot stand alone) to 5 (can easily get up and remain standing without help) and a walking score ranging from 1 (cannot do one active step) to 5 (completely independent walking). Both scores have previously been described [22].

During the study all falls and fractures were registered by the nursing staff on special forms and checked with the routine incident registration. At the end of each study period in a nursing home, every ward was asked to complete a questionnaire on the opinion of the nursing staff about the suitability of each distribution form, compliance, the risk of making mistakes, time investment and preferences.

Random samples of the returned medication were counted in order to verify compliance.

Adequate compliance was defined to exist when more than $80 \%$ of the study medication was ingested. Twice a quality check was made on the research medication by taking random samples for determining the vitamin D3 content of tablets and 
powders. Fasting blood samples were obtained at baseline, at two and four months.

Serum $25(\mathrm{OH}) \mathrm{D}$ was measured by radioimmunoassay (Diasorin, Stillwater, MN) with an inter-assay coefficient of variation $(\mathrm{CV})$ of $10 \%$ at $30 \mathrm{nmol} / \mathrm{L}$. Serum PTH was measured by radioimmunoassay (Incstar, San Juan Capistrano, CA) with an inter-assay $\mathrm{CV}$ of $10 \%$ at $3.5 \mathrm{pmol} / \mathrm{L}$. Serum carboxy-terminal collagen crosslinks or CTX, a marker for bone resorption, was measured by immuno-assay (CrossLaps, (Roche) with an interassay CV of $5 \%$.

For these parameters the sera of a single participant were all measured within the same run to decrease variation. Serum calcium, phosphate, albumin, creatinine and alkaline phosphatase $(\mathrm{APh})$ were measured using standard laboratory procedures, immediately after obtaining the blood samples. Serum calcium was corrected for serum albumin using the formula:

$$
\begin{aligned}
& \text { corrected calcium }(\mathrm{mmol} / \mathrm{L})= \\
& \text { measured }[\text { calcium }]+(40-\text { albumin }(\mathrm{g} / L)) \times 0.02
\end{aligned}
$$

Statistical analysis

Statistical analysis was performed using SPSS 12.0.1. Data are presented as means (and standard deviation [SD]) or in case of skewed distributions - as medians (and interquartile range $[\mathrm{IQR}])$. Associations between baseline serum 25(OH)D and PTH, PTH and AF, and AF and CTX were examined by means of the Pearson correlation coefficient or - when one or both outcome variables had a skewed distribution - the Spearman rank order correlation coefficient. Baseline characteristics of dropouts and completers were compared by logistic regression analysis. Linear multilevel analysis with SPSS Mixed Models was used to investigate: (1) the effect of vitamin D supplementation on change (from baseline $\left(t_{0}\right)$ to 4 months $\left(t_{2}\right)$ ) in biochemical outcome variables (serum 25(OH)D, serum PTH, bone turnover markers) and (2) the effect of additional calcium supplementation on change (from 4 months $\left(t_{2}\right)$ to 4.5 months $\left.\left(t_{3}\right)\right)$ in biochemical outcome variables, adjusting for possible clustering of observations. The included levels were repeated measures (i.e., time), respondent, and nursing home. Nursing home was included in the final analyses only in case of a change of the effect size of more than $10 \%$. Separate models were created with 25(OH)D, phosphate, corrected calcium, CTX, PTH, and $\mathrm{APh}$ as the respective dependent variables. We examined the potential confounding effect of season, age, sex, mean daily calcium intake, creatinine, standing and walking score at $\mathrm{t}_{0}$. For $\mathrm{PTH}$ and $\mathrm{APh}$, logarithmic transformations were performed to normalize variance to allow parametric tests. For these log-transformed outcome variables, the estimated mean difference between two intervention groups was transformed back using an antilog transformation. The resulting estimate is the ratio of the geometric means of the outcome variable in both intervention groups. The geometric mean resembles the median. The level of significance was set at $P<0.05$.

\section{Results}

Baseline characteristics

Table 1 shows the baseline characteristics of the 338 participants enrolled in the study. These were very similar for the different intervention groups. In the total group, baseline mean serum 25(OH)D was $25.0 \mathrm{nmol} / \mathrm{L}$ (SD 10.9). In $55 \%$ of the participants, serum $25(\mathrm{OH}) \mathrm{D}$ was lower than $25 \mathrm{nmol} / \mathrm{L}$ while $77 \%$ had levels below $30 \mathrm{nmol} / \mathrm{L}$ and $98 \%$ below $50 \mathrm{nmol} / \mathrm{L}$ (data not shown). Baseline median serum PTH was $7.2 \mathrm{pmol} / \mathrm{L}$ (IQR 5.1-10.5) (ref. values: 1$11 \mathrm{pmol} / \mathrm{L})$. There were statistically significant correlations at baseline between serum $25(\mathrm{OH}) \mathrm{D}$ and serum PTH values $(\mathrm{r}=-0.25 ; P<0.001)$, serum $\mathrm{PTH}$ and serum $\mathrm{APh}$ values $(\mathrm{r}=$ $0.16 ; P<0.01)$, and serum $\mathrm{APh}$ and serum CTX values $(\mathrm{r}=$ $0.23 ; P<0.001$ ) (data not shown). The median daily calcium intake from dairy products was $750 \mathrm{mg}$ (IQR 560-1035).

\section{Trial schedule}

Figure 1 shows the trial schedule as well as the results of the randomisation procedure of both the vitamin D and the calcium intervention. Of the 341 participants originally enrolled, three were enrolled incorrectly because of hypercalcemia (corrected serum calcium: 2.69; 2.83; and 2.85), leaving 338 participants eligible for the study.

\section{Vitamin D intervention}

The 338 enrolled participants were randomised to treatment with vitamin D3 one tablet of 600 IU each day $(n=55)$, a placebo in the form of one tablet each day $(n=57)$, vitamin D3 in the form of seven tablets (4200 IU) once a week $(n=54)$, a placebo in the form of seven tablets once a week $(n=58)$, vitamin D3 in the form of one powder once a month $(n=57)$, or a placebo in the form of one powder of 1,800 IU once a month $(n=57)$. The treatment period of four months was completed by 276 participants. Of the 62 drop-outs, 41 died during the study period and there were 21 withdrawals: nine participants became terminally ill; five participants became uncooperative to donate a blood sample; one participant showed signs of discomfort during blood sampling; one participant became immobile; 3 participants were moved elsewhere; and one participant dropped out for unknown reasons. Finally, one participant was excluded from the analyses due to extremely high 
Table 1 Characteristics of 338 participants at baseline $\left(\mathrm{t}_{0}\right)$ by intervention group at $\mathrm{t}_{0}(\mathrm{Pl} \mathrm{D}=$ placebo vitamine $\mathrm{D}, \mathrm{D}=\mathrm{vitamin} \mathrm{D})$ and $\mathrm{t}_{2}(\mathrm{Pl} \mathrm{Ca}=\mathrm{placebo}$ calcium, $\mathrm{Ca}=$ calcium)

\begin{tabular}{|c|c|c|c|c|c|c|c|c|}
\hline & $\begin{array}{l}\text { Total } \\
(n=338)\end{array}$ & $\begin{array}{l}\text { D total } \\
(n=166)\end{array}$ & $\begin{array}{l}\mathrm{D} \text { daily } \\
(n=55)\end{array}$ & $\begin{array}{l}\text { D weeky } \\
(n=54)\end{array}$ & $\begin{array}{l}\text { D monthly } \\
(n=57)\end{array}$ & $\begin{array}{l}\text { P1 D total } \\
(n=172)\end{array}$ & $\begin{array}{l}\mathrm{Ca}^{\mathrm{b}} \\
(n=68)\end{array}$ & $\begin{array}{l}\mathrm{Pl} \mathrm{Ca} \\
(n=71)\end{array}$ \\
\hline$\%$ female & 77.5 & 76.5 & 83.6 & 72.2 & 73.7 & 78.5 & 76.5 & 78.9 \\
\hline Variable & Mean (SD) & Mean (SD) & Mean (SD) & Mean (SD) & Mean (SD) & Mean (SD) & Mean (SD) & Mean (SD) \\
\hline Age (yr) & $84.2(6.2)$ & $84.2(6.5)$ & $84.3(6.3)$ & $84.3(6.4)$ & $83.9(6.9)$ & $84.2(5.9)$ & $83.3(6.2)$ & $84.5(6.8)$ \\
\hline $25(\mathrm{OH}) \mathrm{D}(\mathrm{nmol} / \mathrm{L})$ & $25.0(10.9)$ & $24.9(10.1)$ & $24.0(8.6)$ & $26.7(12.6)$ & $24.1(8.8)$ & $25.0(11.7)$ & $25.3(10.6)$ & $24.1(9.6)$ \\
\hline $\begin{array}{l}\text { Calcium corrected } \\
(\mathrm{mmol} / \mathrm{L})\end{array}$ & $2.42(0.10)$ & $2.42(0.09)$ & $2.42(0.09)$ & $2.41(0.08)$ & $2.42(0.10)$ & $2.43(0.10)$ & $2.41(0.08)$ & $2.42(0.10)$ \\
\hline $\begin{array}{l}\text { Phosphate } \\
(\mathrm{mmol} / \mathrm{L})\end{array}$ & $1.03(0.14)$ & $1.02(0.14)$ & $1.02(0.13)$ & $1.02(0.16)$ & $1.02(0.13)$ & $1.04(0.14)$ & $1.01(0.14)$ & $1.03(0.13)$ \\
\hline CTX (ng/L) & $592(277)$ & $571(274)$ & $594(274)$ & $626(311)$ & $496(218)$ & $613(280)$ & $552(288)$ & $565(255)$ \\
\hline Albumin $(\mathrm{g} / \mathrm{L})$ & $33.4(3.3)$ & $33.4(3.3)$ & $33.0(3.5)$ & $33.1(3.4)$ & $34.2(2.8)$ & $33.4(3.2)$ & $34.0(3.2)$ & $33.0(3.4)$ \\
\hline $\begin{array}{l}\text { Standing score } \\
(1-5)\end{array}$ & $3.3(1.6)$ & $3.3(1.6)$ & $3.5(1.6)$ & $3.1(1.7)$ & $3.5(1.6)$ & $3.3(1.6)$ & $3.2(1.7)$ & $3.5(1.6)$ \\
\hline $\begin{array}{l}\text { Walking score } \\
(1-5)\end{array}$ & $3.0(1.4)$ & $3.0(1.4)$ & $3.0(1.4)$ & $3.0(1.6)$ & $3.0(1.3)$ & $3.0(1.4)$ & $2.9(1.4)$ & $3.1(1.4)$ \\
\hline Skewed variable & $\begin{array}{l}\text { Median } \\
\text { (IQR) }\end{array}$ & $\begin{array}{l}\text { Median } \\
\text { (IQR) }\end{array}$ & $\begin{array}{l}\text { Median } \\
\text { (IQR) }\end{array}$ & $\begin{array}{l}\text { Median } \\
\text { (IQR) }\end{array}$ & $\begin{array}{l}\text { Median } \\
(\mathrm{IQR})\end{array}$ & $\begin{array}{l}\text { Median } \\
(\mathrm{IQR})\end{array}$ & $\begin{array}{l}\text { Median } \\
(\mathrm{IQR})\end{array}$ & $\begin{array}{l}\text { Median } \\
\text { (IQR) }\end{array}$ \\
\hline $\begin{array}{l}\text { Calcium intake } \\
(\mathrm{mg} / \text { day })^{\mathrm{b}}\end{array}$ & $\begin{array}{l}750 \\
(560-1035)\end{array}$ & $\begin{array}{l}750 \\
(594-1015)\end{array}$ & $\begin{array}{l}725 \\
(623-1039)\end{array}$ & $\begin{array}{l}755 \\
(550-1028)\end{array}$ & $\begin{array}{l}788 \\
(583-955)\end{array}$ & $\begin{array}{l}750 \\
(550-1053)\end{array}$ & $\begin{array}{l}773 \\
(614-1024)\end{array}$ & $\begin{array}{l}730 \\
(565-1003)\end{array}$ \\
\hline PTH (pmol/L) & $7.2(5.1-10.5)$ & $7.2(5.2-10.4)$ & $7.4(5.2-10.4)$ & $6.7(5.3-9.9)$ & $7.2(5.1-10.5)$ & $7.1(5.1-11.1)$ & $6.5(5.2-9.4)$ & $7.3(5.1-10.9)$ \\
\hline AF (U/L) & $85(69-102)$ & $86(71-104)$ & $82(73-100)$ & $90(68-106)$ & $87(67-105)$ & 85 (69-99) & $89(68-105)$ & $82(67-98)$ \\
\hline Creatinine $(\mu \mathrm{mol} / \mathrm{L})$ & $93(81-103)$ & $92(81-103)$ & $87(80-95)$ & $96(85-104)$ & $94(81-105)$ & $93(82-105)$ & $91(80-102)$ & $92(81-102)$ \\
\hline
\end{tabular}

$\mathrm{IQR}=$ interquartile range

${ }^{\mathrm{a}}$ From dairy products

${ }^{\mathrm{b}}$ Within participants completing the vitamin $\mathrm{D}$ intervention $(n=276)$ treated with vitamin $\mathrm{D}(n=139)$

Fig. 1 Flow diagram of progress through the randomized clinical trial of vitamin D supplementation followed by the randomized clinical trial of calcium supplementation

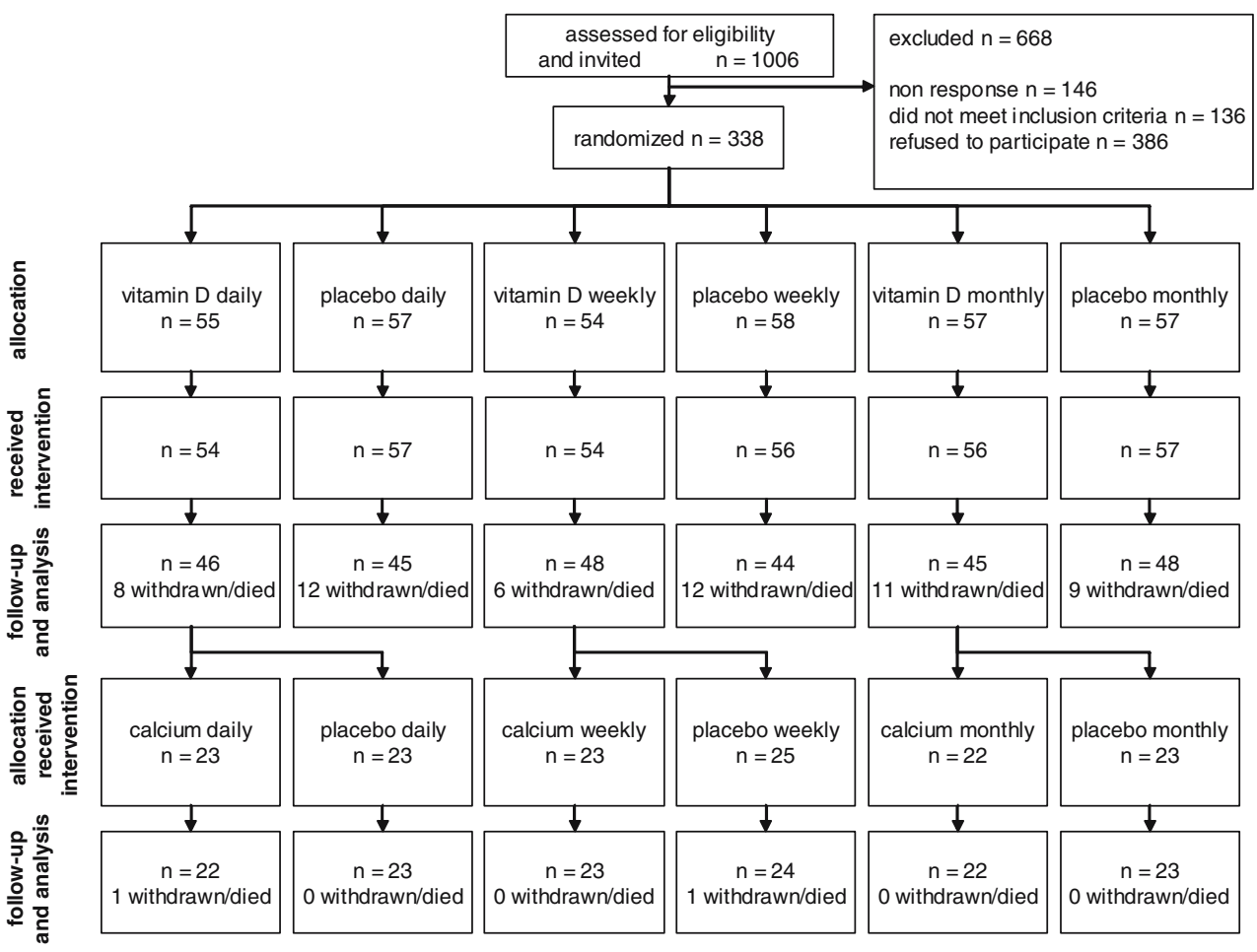




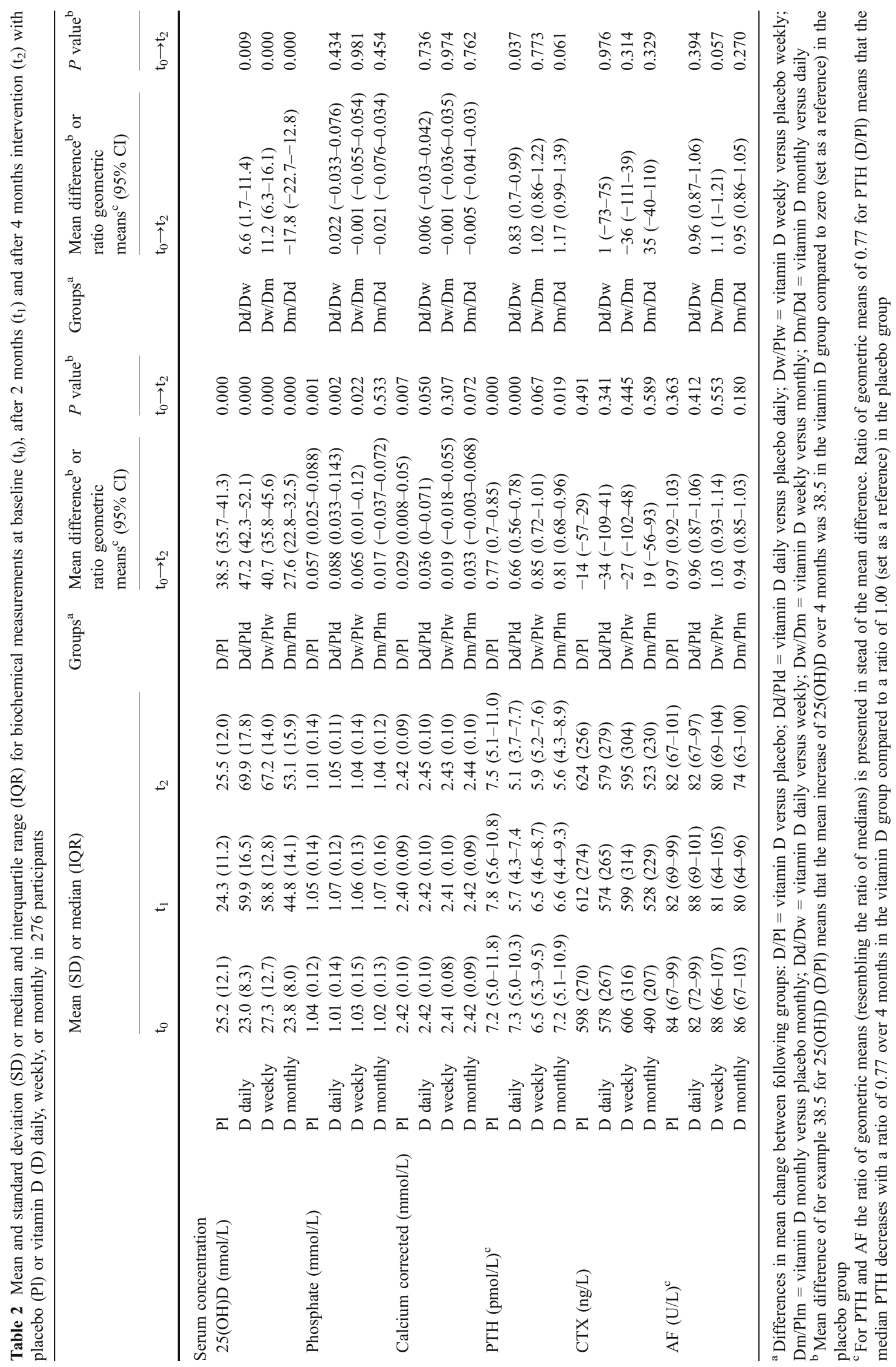


levels of alkaline phosphatase $(278,1025,2661 \mathrm{U} / \mathrm{L}$ at, respectively, $t_{0}, t_{1}, t_{2}$ ) for unknown reasons (further analysis was refused by the patient). The number of drop-outs did not differ significantly between the placebo $(n=35)$ and the vitamin D group $(n=27)$. Dropouts were similar to completers with respect to most baseline characteristics (sex, age, $25(\mathrm{OH}) \mathrm{D}$, corrected calcium, phosphate, albumin, standing score, walking score, mean daily calcium intake, and creatinine), but had higher serum levels of CTX, and APh $(P<0.05)$ (data not shown).

\section{Calcium intervention}

The 276 participants who completed the vitamin D intervention study were randomised to treatment with calcium one tablet each day $(n=138)$, or placebo one tablet each day $(n=138)$. The treatment period of 14 days was completed by 269 participants. Of the seven drop-outs, three died, three became terminally ill and one participant dropped out for unknown reasons. Only those treated with vitamin $\mathrm{D}$ were included in the analysis of the calcium intervention ( $n=68$ for calcium; $n=71$ for placebo); there was only one drop-out in each group.

\section{Effectiveness of Vitamin D supplementation}

Nursing home and potential confounding variables at baseline were not included in the final models since the effect sizes were hardly influenced by adding these variables.

\section{Serum 25-hydroxyvitamin D}

Effects of vitamin D supplementation on serum 25(OH)D in the various treatment groups are shown in Table 2 and Fig. 2. The mean difference in increase of serum $25(\mathrm{OH}) \mathrm{D}$ was $38.5 \mathrm{nmol} / \mathrm{L}$ (95\% confidence interval (CI) 25.6-41.5) in favour of vitamin D when compared to placebo. Daily, weekly and monthly administration of vitamin $\mathrm{D}$ resulted in increase of serum 25(OH)D when compared to placebo $(P<$ $0.001)$. The mean difference in increase of serum $25(\mathrm{OH}) \mathrm{D}$ was highest after 4 months with daily administration of vitamin $\mathrm{D}$ (mean $47.2 \mathrm{nmol} / \mathrm{l}$ ) when compared to weekly (mean $40.7 \mathrm{nmol} / \mathrm{l}, P<0.01$ ) and monthly (mean $27.6 \mathrm{nmol} / \mathrm{l}$, $P<0.001)$ administration. Weekly administration of vitamin D resulted in a greater increase of serum $25(\mathrm{OH}) \mathrm{D}$ than monthly administration $(P<0.001)$. The percentage of patients with serum $25(\mathrm{OH}) \mathrm{D}$ below cut offs of $25 \mathrm{nmol} / \mathrm{l}, 50 \mathrm{nmol} / \mathrm{l}$ and $75 \mathrm{nmol} / \mathrm{l}$ is shown in Table 3 . At 4 months, the percentage of patients with serum $25(\mathrm{OH}) \mathrm{D}<50 \mathrm{nmol} / 1$ was $10.9,10.6$ and $36.4 \%$ in the daily, weekly and monthly groups of vitamin D supplementation respectively. $\multimap$ placebo $\longrightarrow$ daily vitamin $D$...... weekly vitamin $D \multimap$ monthly vitamin $D$

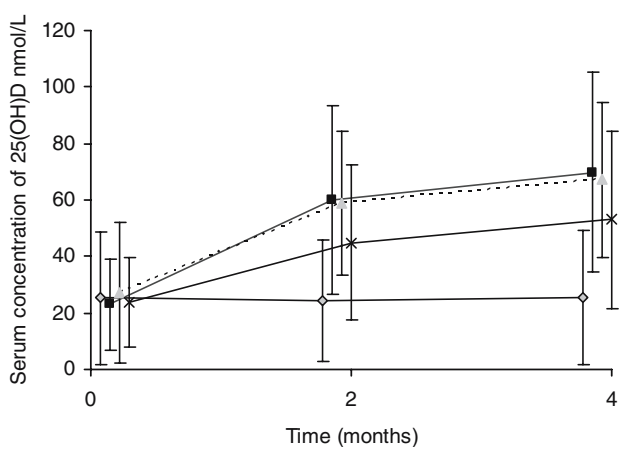

Fig. 2 Mean $( \pm 1.96 \times \mathrm{SD})$ serum $25(\mathrm{OH}) \mathrm{D}$ concentrations at baseline, 2 and 4 months during treatment with vitamin $\mathrm{D}$ daily, weekly, or monthly, or placebo

Secondary outcome measures: serum phosphate and corrected calcium

Serum phosphate and corrected serum calcium values increased significantly more in the vitamin D group than in the placebo group. However, no differences between daily, weekly, or monthly administration were found (Table 2).

Serum parathyroid hormone and bone turnover markers

Effects of vitamin D supplementation on serum PTH, serum $\mathrm{APh}$ and CTX in the various treatment groups are shown in Table 2. Serum PTH $(P<0.000)$ decreased in the vitamin D group from 7.2 to $5.5 \mathrm{pmol} / 1$ when compared to placebo, which is a decrease of $23 \%$ (ratio $0.77,95 \%$ CI $0.70-0.85$, $\mathrm{P}<0.001$ ). The decrease of serum PTH was greater with daily administration of vitamin $\mathrm{D}$ when compared to weekly $(P<0.05)$ and monthly $(P<0.10)$ administration. The difference between weekly and monthly administration of vitamin $\mathrm{D}$ was not significant. The serum concentrations of alkaline phosphatase and CTX did not change following vitamin D supplementation.

\section{Effectiveness of calcium supplementation}

There was no effect of calcium supplementation on any of the six biochemical outcome variables when compared to placebo. Also after stratification by administration of vitamin D (daily, weekly or monthly), an effect of calcium supplementation was not observed except for corrected calcium levels which increased more in the calcium group than in the placebo group in the daily dose vitamin $\mathrm{D}$ group only $(P<$ $0.05)$. No effect was found of calcium doses $(800 \mathrm{mg}$ vs $1,600 \mathrm{mg}$ calcium carbonate). Adding nursing home and other potential confounding variables at baseline did not influence the results. 
Table 3 Percentage of participants with 25(OH)D levels below a certain cut-off point at baseline and after vitamin $\mathrm{D}$ or placebo supplementation

\begin{tabular}{lllllll}
\hline Group: & Total & Placebo & $\begin{array}{l}\text { Vitamin D } \\
\text { total }\end{array}$ & $\begin{array}{l}\text { Vitamin D } \\
\text { daily }\end{array}$ & $\begin{array}{l}\text { Vitamin D } \\
\text { weekly }\end{array}$ & $\begin{array}{l}\text { Vitamin D } \\
\text { monthly }\end{array}$ \\
\hline 25(OH)D $<25 \mathrm{nmol} / \mathrm{L}$ & & & & & & \\
$\quad$ Baseline (t0) & 55.3 & 56.9 & 53.6 & 60.9 & 48.9 & 51.1 \\
2 months (t1) & 30.1 & 57.8 & 2.9 & 2.2 & 0.0 & 6.8 \\
4 months (t2) & 27.4 & 52.6 & 2.2 & 2.2 & 0.0 & 4.5 \\
25(OH)D<50 nmol/L & & & & & & \\
Baseline (t0) & 97.5 & 96.4 & 98.6 & 100.0 & 95.7 & 100.0 \\
2 months (t1) & 65.4 & 94.8 & 36.5 & 26.1 & 19.1 & 65.9 \\
4 months (t2) & 58.0 & 97.1 & 19.0 & 10.9 & 10.6 & 36.4 \\
$25(\mathrm{OH}) \mathrm{D}<75 \mathrm{nmol} / \mathrm{L}$ & & & & & & 100.0 \\
Baseline (t0) & 99.6 & 99.3 & 100.0 & 100.0 & 100.0 & 97.7 \\
2 months (t1) & 95.2 & 99.3 & 91.2 & 87.0 & 89.4 & 95.5 \\
4 months (t2) & 88.3 & 100.0 & 76.6 & 63.0 & 72.3 & \\
\hline
\end{tabular}

\section{Fractures}

The number of falls and fractures did not differ between the intervention groups and the control groups, which was expected given the short study period of four and a half months.

\section{Compliance}

The compliance assessed within 96 random samples of the returned medication was good. In the daily administration group, all 33 participants were compliant-i.e., used at least $80 \%$ of the tablets $-($ median $=97.0$; IQR 94.5-100). For weekly administration, $80 \%$ of the 35 participants were compliant-i.e., used at least $80 \%$ of the tablets (median= 98.5; IQR 84.0-100). For monthly administration, 93\% of the 28 participants were compliant-i.e., used at least four out of five powders (median=100; IQR 85.0-100).

\section{Survey nursing staff}

A survey among the nursing staffs of the participating nursing home wards showed a distinct preference (72\%) for daily administration compared to weekly and monthly. Thirty-ning percent of the nursing staffs reported the impression that fewer mistakes were made using daily administration instead of weekly or monthly administration.

\section{Discussion}

The results of this study confirm the poor vitamin D status often observed in institutionalised elderly. In this study, baseline serum $25(\mathrm{OH}) \mathrm{D}$ levels in these nursing home residents was comparable to those observed in other studies in institutionalized elderly in the Netherlands [2, 3], resulting in median serum PTH levels in the upper normal range. A negative correlation between serum PTH and serum $25(\mathrm{OH})$ D was observed, confirming other studies [4].
In all treatment groups oral vitamin D supplementation appeared to be effective, resulting in increasing serum 25 $(\mathrm{OH}) \mathrm{D}$ levels and decreasing serum PTH levels as observed in other studies [3, 4, 23]. However, no effect was seen on serum alkaline phosphatase and CTX levels.

Daily administration of vitamin D3 was significantly more effective than weekly and monthly administration. This could be due to more regular absorption in the gut or better compliance. The percentage of participants with serum 25 $(\mathrm{OH}) \mathrm{D}<50 \mathrm{nmol} / \mathrm{l}$ after four months of supplementation was about $10 \%$ in the daily and weekly groups, but was more than $35 \%$ in the monthly group. An option would be to increase the dose when vitamin $\mathrm{D}$ is supplemented only once per month. The dose of $600 \mathrm{IU} /$ day was chosen according to the Dutch and US recommendations $[4,18]$. In order to attain a higher percentage of people with serum $25(\mathrm{OH}) \mathrm{D}>50 \mathrm{nmol} / \mathrm{l}$, the dose of vitamin D should be 700-800 IU/day as was recommended for patients with osteoporosis in a recent review [24].

The overall decrease of serum PTH was $23 \%$ with vitamin D supplementation, which corresponds to our previous vitamin D supplementation study in a nursing home [15] and which is a larger decrease than that observed in healthy independently living elderly women where the decrease of serum PTH was $15 \%$ [8]. This is consistent with the more severe vitamin D deficiency and the greater degree of secondary hyperparathyroidism observed in these, mainly psychogeriatric, nursing home residents. Improvement of vitamin D status and suppression of PTH secretion may reduce bone turnover and bone loss, increase bone mineralization and thereby reducing fracture risk, although this was not the subject of this study.

For calcium supplementation, calcium citrate, lactate or carbonate can be used. In this study, calcium carbonate was used based upon bioavailability, cost and clinical efficacy [25]. The absorption of calcium from dairy products is about similar to that from calcium carbonate [26, 27]. Because of the side effects of calcium carbonate (gastrointestinal 
irritation, constipation, belches), possibly more pronounced in a population of frail elderly with substantial comorbidity and comedication, one should not choose a too high supplementation dose. Given the expected dietary calcium intake of about $900 \mathrm{mg}$ per day, two supplementation doses $800 \mathrm{mg}$ calcium carbonate $(320 \mathrm{mg} \mathrm{Ca} 2+)$ and $1,600 \mathrm{mg}$ calcium carbonate (640 $\mathrm{mg} \mathrm{Ca} 2+$ ), respectively) were used.

The median calcium intake in these Dutch nursing home residents $(750 \mathrm{mg}$ per day from dairy products, total estimated dietary intake $950-1,000 \mathrm{mg}$ per day) was slightly lower than the guidelines recommend and relatively high compared to institutionalised elderly in other countries, probably due to a higher dairy intake. This was expected since every Dutch nursing home has its own dietician. Calcium supplementation combined with vitamin $\mathrm{D}$ in the last part of the study did not lead to a decrease of biochemical markers of bone turnover. An explanation might be that immobility is a cause of high bone turnover, which is not suppressed by calcium supplementation. The nursing staff's preference for daily supplementation of vitamin $\mathrm{D}$ is probably due to the fact that it fits better in a regular distribution routine, is less time consuming and less susceptible for making mistakes.

In conclusion, $98 \%$ of the participants had a baseline serum $25(\mathrm{OH}) \mathrm{D}$ lower than $50 \mathrm{nmol} / \mathrm{L}$. Oral vitamin $\mathrm{D} 3$ supplementation, administered daily was more effective than weekly doses in nursing home residents, while monthly administration was the least effective, $35 \%$ still having a serum $25(\mathrm{OH}) \mathrm{D}<50 \mathrm{nmol} / 1$ after 4 months treatment in this group. Calcium supplementation did not augment the effect of vitamin D supplementation.

Acknowledgements We thank Jeannet van Rijn and the laboratory workers of the participating nursing homes for taking care of the blood samples. We thank the patients, the nursing home physicians, secretaries and nursing staffs of the participating nursing homes for their assistance with the study; Henriette Philippo, dietician in Mariënhaven, for help with assessment of calcium intake, Jannie van Leeuwen from Mariënhaven for her administrative support and Solvay Pharmaceuticals for supplying the research medication. The practical assistance of Els Lommerse-Rusman and Greetje Asma in conducting the study is acknowledged. The department of Clinical Chemistry and Laboratory for Endocrinology of the VU University Medical Center (VUMC) are acknowledged for biochemical estimations. The advice of Dirk Knol for the statistical evaluation is acknowledged. This study was financially supported by ZonMw, the Netherlands Organization for Health Research and Development, the Hague.

\section{References}

1. Van der Wielen RPJ, Lowik MRH, van de Berg H, de Groot LCP, Haller J, Moreiras O, van Staveren WA (1995) Vitamin D concentrations among elderly people in Europe. Lancet 346:207-210
2. Lips P, Ginkel van FC, Jongen MJM, Rubertus F, Vijgh van der WJF, Netelenbos JC (1987) Determinants of vitamin D status in patients with hip fracture and in elderly control subjects. Am J Clin Nutr 46:1005-1010

3. Lips P, Wiersinga A, Ginkel van FC, Jongen MJM, Netelenbos JC, Hackeng WHL, Delmas PD, Vijgh van der WJF (1988) The effect of vitamin D supplementation on vitamin D status and parathyroid function in elderly subjects. J Clin Endocrinol Metab 67:644-650

4. Lips P (2001) Vitamin D deficiency and secondary hyperparathyroidism in the elderly: consequences for bone loss and fractures and therapeutic implications". Endocrine Rev 22:477-501

5. Pfeifer M, Begerow B, Minne W (2002) Vitamin D and muscle function. Osteoporos Int 13:187-194

6. Snijder MB, van Schoor NM, Pluijm SMF, van Dam RM, Visser M, Lips P (2006) Vitamin D status in relation to one-year risk of recurrent falling in older men and women. J Clin Endocrinol Metab 91:2980-2985

7. Dawson-Hughes B, Dallal GE, Krall EA, Harris S, Sokoll LJ, Falconer G (1991) Effect of vitamin D supplementation on wintertime and overall bone loss in healthy postmenopausal women. Ann Intern Med 115:505-512

8. Ooms ME, Roos JC, Bezemer PD, Vijgh van der WJF, Bouter LM, Lips P (1995) Prevention of bone loss by vitamin D supplementation in elderly women: a randomized double-blind trial. J Clin Endocrinol Metab 80:1052-1058

9. Chapuy MC, Arlot ME, Duboeuf F et al (1992) Vitamin D3 and calcium to prevent hip fractures in elderly women. N Engl J Med 327:1637-1642

10. Lips P, Graafmans WC, Ooms ME, Bezemer PD, Bouter LM (1996) Vitamin D supplementation and fracture incidence in elderly persons. A randomized, placebo-controlled clinical trial. Ann Intern Med 124:400-406

11. Grant AM, Avenell A, Campbell MK, on behalf of the RECORD Trial group (2005) Oral vitamin D3 and calcium for secondary prevention of low-trauma fractures in elderly people (Randomised Evaluation of Calcium or Vitamin D, RECORD): a randomised placebo-controlled trial. Lancet 365:1621-1628

12. Porthouse J, Cockayne S, King C et al (2005) Randomised controlled trial of calcium and supplementation with cholecalciferol (vitamin D3) for prevention of fractures in primary care. BMJ 330:1003

13. Dawson-Hughes B, Harris SS, Krall EA, Dallal GE (1997) Effect of calcium and vitamin D supplementation on bone density in men and women 65 years of age or older. N Engl J Med 337:670-676

14. Trivedi DP, Doll R, Khaw KT (2003) Effect of four-monthly oral vitamin D3 (cholecalciferol supplementation on fractures and mortality in men and women living in the community: randomized double-blind controlled trial. BMJ 326:469

15. Chel VGM, Ooms ME, Popp-Snijders C, Pavel S, Schothorst AA, Meulemans CCE, Lips P (1998) Ultraviolet irradiation corrects vitamin D deficiency and suppresses secondary hyperparathyroidism in the elderly. J Bone Miner Res 13:1238-1242

16. Malabanan AO, Veronikis IE, Holick MF (1998) Redefining vitamin D insufficiency. Lancet 351:805-806

17. Dawson-Hughes B, Heaney RP, Holick MF, Lips P, Meunier PJ, Vieth R (2005) Estimates of optimal vitamin D status. Osteoporosis Int 16:713-716

18. Gezondheidsraad (2000) Voedingsnormen: calcium, vitamine D, thiamine, riboflavine, niacine, pantotheenzuur en biotine. Den Haag: Gezondheidsraad; publicatie nr 2000/12

19. Steingrimsdottir L, Gunnarsson O, Indridason OS, Franzson L, Sigurdsson G (2005) Relationship between serum parathyroid hormone levels, vitamin D sufficiency, and calcium intake. JAMA 294:2336-2341

20. Heaney RP (2001) Calcium needs of the elderly to reduce fracture risk. J Am Coll Nutr 20(suppl 2):192S-197S 
21. Elders PJM, Netelenbos JC, Lips P et al (1989) Perimenopausal bone mass and risk factors. Bone Miner 7:123-132

22. Lips P, Ginkel van FC, Netelenbos JC, Wiersinga A, Vijgh van der WJF (1990) Lower mobility and markers of bone resorption in the elderly. Bone Miner 9:49-57

23. Lips P, Duong T, Oleksik AM, Black D, Cummings S, Cox D, Nickelsen T, for the MORE Study Group (2001) A global study of vitamin $\mathrm{D}$ status and parathyroid function in postmenopausal women with osteoporosis: baseline data from MORE clinical trial. J Clin Endocrinol Metab 86:1212-1221
24. Bischoff-Ferrari HA (2007) How to select the doses of vitamin D in the management of osteoporosis. Osteoporos Int 18:401-407

25. Heaney RP, Dowell MS, Bierman J et al (2001) Absorbability and cost effectiveness in calcium supplementation. J Am Coll Nutr 20(3):239-246

26. Rodriguez-Martinez MA, Garcia-Cohen EC (2002) Role of Ca 2+ and vitamin $\mathrm{D}$ in the prevention and treatment of osteoporosis. Pharmacol Ther 93(1):37-49

27. Recker RR, Bammi A, Barger-Lux MJ et al (1988) Calcium absorbability from milk products, an imitation milk and calcium carbonate. Am J Clin Nutr 47:93-95 